Proc. Estonian Acad. Sci. Geol., 2006, 55, 2, 109-127

\title{
The Early Ordovician trilobite distribution and zonation of the East Baltic
}

\author{
Helje Pärnaste \\ Institute of Geology at Tallinn University of Technology, Estonia pst. 7, 10143 Tallinn, Estonia; \\ helje@gi.ee \\ Received 7 November 2005, in revised form 6 December 2005
}

\begin{abstract}
Biozones of the East Baltic Early Ordovician trilobites were studied based on the trilobite distribution in northwestern Russia, Estonia, and Sweden. New data on trilobite distribution reveal the diachroneity of the lowest calcareous

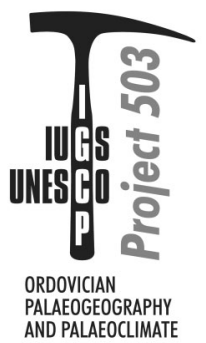
sediments of the Mäeküla Member, which forms the upper part of the Leetse Formation in the East Baltic. Trilobites of the Tremadoc Apatokephalus serratus and Megistaspis (Ekeraspis) armata biozones are missing in the East Baltic, in contradiction to the suggestion of Balashova (Vopr. Paleontol., 1966, 5, 3-22). Some poorly preserved specimens probably belonging to Megistaspis (Paramegistaspis) planilimbata (Angelin) and also records of Pliomerops? linnarssoni (Wiman) indicate that the Arenig Megistaspis (P.) planilimbata Biozone of the Hunneberg Stage may be represented in some localities. The final delimitation of biozones in the Mäeküla and Päite members should improve when the ontogenetic and phylogenetic variation of the M. (Paramegistaspis) lineage has been fully documented. Until then the Evropeites lamanskii Biozone is used in the East Baltic following Balashova, as indicated by the appearance of that taxon in most studied localities, marking the beginning of the Billingen Age. The succeeding Megalaspides (Megalaspides) dalecarlicus Biozone is represented by the occurrence of at least its upper part in the Vassilkovo Beds in the St. Petersburg region, where Megalaspides paliformis Tjernvik occurs together with the index taxon (these taxa co-occur in the upper part of this zone in Sweden). The Päite Member in the East Baltic is correlated with the Megistaspis (P.) estonica Biozone of the upper part of the Billingen Stage in Sweden.
\end{abstract}

Key words: trilobites, biozonation, Hunneberg, Billingen, Lower Ordovician, Baltoscandia.

\section{INTRODUCTION}

The aim of this study was to investigate the distribution of the trilobites of the lowest part of the Ordovician limestone succession in the East Baltic and to observe their zonation in comparison with Scandinavian trilobite biozones. In the studied area trilobites are very rare in the lowest calcareous sediments of the 
Ordovician succession. Fewer than 60 specimens assigned to 18 species were previously recorded from the calcareous glauconitic sandstone of the Mäeküla Member (Schmidt 1904, 1907; Lamansky 1905; Öpik 1937; Balashova 1961, 1966). Most of this material was revised by Balashova (1966). Subsequent revision showed that only 15 species of the above 18 are valid (Pärnaste 2003). The majority of specimens came from the Popovka River district close to Pavlovsk, the remainder from localities along the banks of the Tosna, Izhora, Luga, Lava, and Volkhov rivers of northwestern Russia, and only seven were from northern Estonia (NE: Päite, Toila, and Lüganuse; NW: Mäeküla and Paldiski; Fig. 1).

The trilobite distribution and zonation were used in chronostratigraphic subdivision by Lamansky (1905). He subdivided the Series B in the East Baltic into three subseries $\left(\mathrm{B}_{\mathrm{I}}, \mathrm{B}_{\mathrm{II}}\right.$, and $\left.\mathrm{B}_{\mathrm{III}}\right)$ and these in their turn into several stages. Two stages, $\mathrm{B}_{\mathrm{I}} \beta$ and $\mathrm{B}_{\mathrm{II}} \alpha$, include the lowermost calcareous part of the section and are treated in this paper (Fig. 2). According to Lamansky (1905), the calcareous Glauconite Sandstone $\left(\mathrm{B}_{\mathrm{I}} \beta\right)$ contains trilobites of the Megalaspides Zone and is a correlative roughly of the Phyllograptus-skiffer in Sweden and Norway. The overlying stage $\left(\mathrm{B}_{\mathrm{II}} \alpha\right)$ of glauconitic limestone is characterized by the occurrence of Megistaspis planilimbata, M. limbata, and Asaphus priscus and is thus a correlative of the Planilimbata- and Limbatakalk in Sweden and Norway (Lamansky 1905, p. 104, table). Öpik (1937, p. 103) correlated $\mathrm{B}_{\mathrm{I}} \beta$ with the somewhat older Ceratopyge Limestone, and Tjernvik (1956, p. 184) suggested that $B_{I} \beta$ together with $\mathrm{B}_{\mathrm{I}} \gamma$, which was established by Jaanusson (1951), may correspond to the Megalaspides dalecarlicus Biozone established by him in Sweden. Balashova (1966) distinguished six local trilobite zones in the East Baltic, five in $\mathrm{B}_{\mathrm{II}} \alpha$ and one in $\mathrm{B}_{\mathrm{I}} \beta$. The last was correlated with the Tremadoc Apatokephalus serratus Biozone. Her assumption was based on several erroneous identifications discussed below. The latest studies on trilobites suggest that the lowest part of the Ordovician calcareous succession in the East Baltic is of Billingen or partly of Hunneberg age (Pärnaste 2004a, b; Fig. 2).

The boundary between the Hunneberg and Billingen "groups" (later referred to as stages, substages or series) was placed between the Megistaspis (Paramegistaspis) planilimbata and Megalaspides dalecarlicus trilobite biozones when established

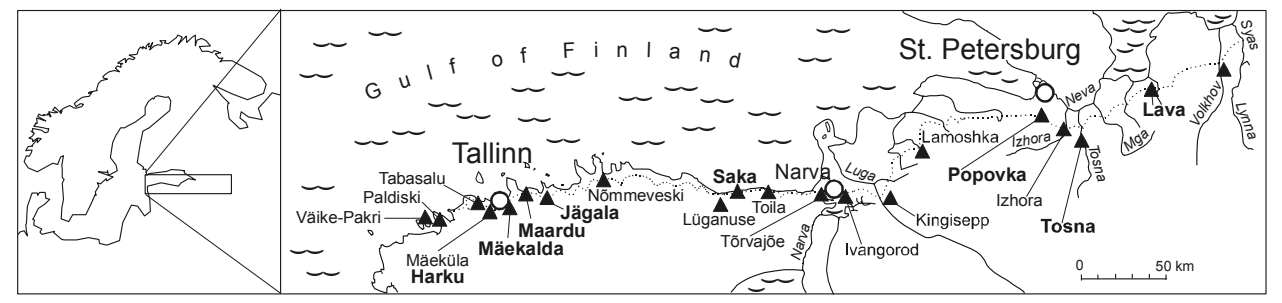

Fig. 1. Map of North Estonian and St. Petersburg regions showing sampled localities. The names of the sections sampled bed by bed are written in bold. The dotted line shows the Baltic-Ladoga Klint (escarpment). 


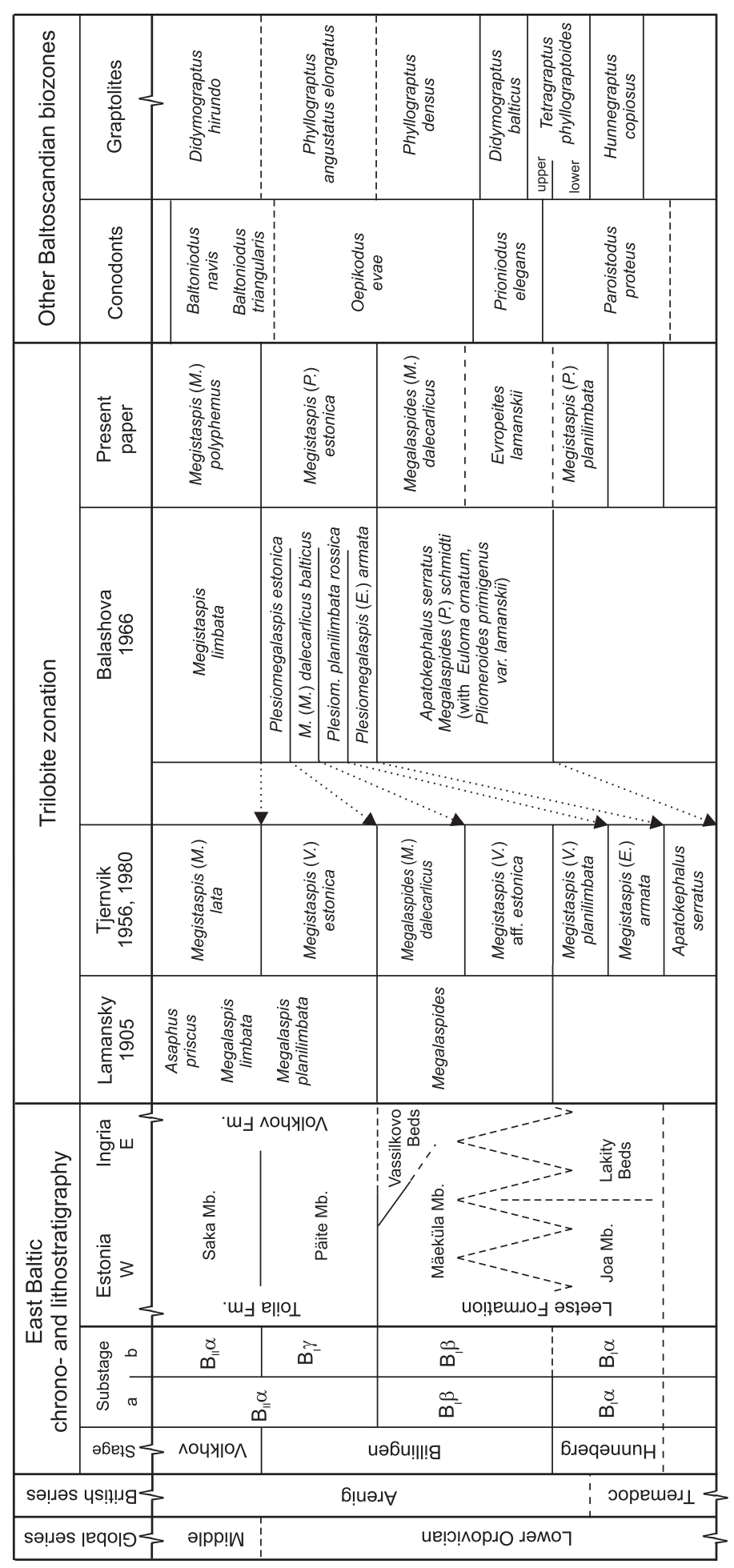

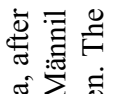

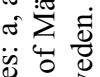

40

跑定.

范

.

更

$\dot{8} \mathrm{Q}$

응 귤

墕

0 흥

年

항

䆙它

उु

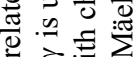

ต

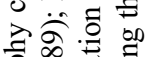

행을

बٓ

के.$\Xi \frac{8}{8}$

要

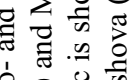

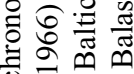

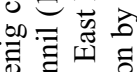

安密

可 $\Xi$

응 क्

을

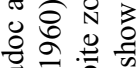

롤을

एᄒ

울 뭉.

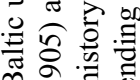

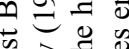

I

싳 
(Tjernvik 1956), coinciding with the lower boundary of the Phyllograptus densus graptolite Biozone. Later, Tjernvik (Tjernvik \& Johansson 1980) agreed with Lindström (1957) that the uppermost strata of the $M$. (P.) planilimbata Biozone with a diverse fauna should be correlated with the Didymograptus balticus Biozone, since in several sections this "Transitional Bed" still contains some survivors from the lower succession but also the first representatives of an "estonica sequence". Thus the boundary between Hunneberg and Billingen was brought down to the lower limit of a new trilobite biozone, the Megistaspis (P.) aff. estonica Biozone (Tjernvik \& Johansson 1980). The last version is followed herein and in my earlier works (Pärnaste 2001a, b, 2003, etc.). However, Lindholm (1991b, p. 287) recommended that the Hunneberg (Series) is better used in its original extent suggested by Tjernvik in 1956, as the unit filling, in Sweden, a hiatus which occurs between Tremadoc and Arenig rocks of the type area (Wales). Since then, both versions have been used, or alternately the inclusive Latorp Stage (established by Jaanusson 1960), which amalgamates those (sub)stages.

Many relevant conodont studies are available from the study area (Mägi \& Viira 1976; Mägi 1984; Bergström 1988; Mägi et al. 1989; Dronov et al. 1995, 1997a, p. 15, 1997b, p. 22; Viira et al. 2001). Correlation of Baltoscandian conodont zones with those of trilobites (Tjernvik 1956; Tjernvik \& Johansson 1980) and graptolites (Cooper \& Lindholm 1990; Lindholm 1991a) is mainly in agreement with Löfgren (1996). However, there are two exceptions (Fig. 2). First, the lower boundary of the Prioniodus elegans Biozone is slightly shifted upwards relative to that of the M. (P.) aff. estonica Biozone and to that of the upper subzone of the Tetragraptus phyllograptoides Biozone (see Löfgren 1993, 1994, 1997). This interpretation is based on the evidence of the first appearance of Prioniodus elegans Pander somewhat higher in sections (cf. Maletz et al. 1996, figs 4, 5). Second, the Baltoniodus navis-Baltoniodus triangularis Biozone is somewhat lowered in position with respect to the Billingen-Volkhov boundary. This follows from the evidence in sections at Ontika (Mägi 1990, fig. 38) and Aseri (Mägi 1984, fig. 1) in northeastern Estonia. Here, B. triangularis (Lindström), co-occurring with the zonal trilobite $M$. (P.) estonica (Tjernvik), has been identified below the "Püstakkiht" (a specific discontinuity layer with deep borings), together with Stolodus stola (Lindström) above the last appearance of Oepikodus evae Lindström and below the first appearance of B. navis (Lindström). However, as the conodonts may have been redeposited, this assumption should be taken with some caution.

\section{GEOLOGICAL SETTING}

Palaeomagnetic data place the Baltica Palaeocontinent at the temperate southern latitudes in the Early Ordovician, on the eastern side of the Iapetus Ocean. The northwestern part of Baltica was influenced by the Palaeotethys Ocean and the southern part by the Tornquist Sea (Scotese \& McKerrow 1990; Torsvik 1998). The Baltoscandian Palaeobasin was a cool epicontinental sea at 
the margin of the Iapetus. Sediments of the Baltoscandian epicontinental sea show rather low rates of deposition, namely $1-3 \mathrm{~mm} / 1000$ years (Lindström 1971; Jaanusson 1976, 1982). Usually the Ordovician succession is less than $200 \mathrm{~m}$ thick, and is nearly horizontally settled. The deposits are rhythmically bedded, possessing regionally numerous breaks caused by repeated fluctuation of the sea depth, by the occurrence of submarine non-deposition or by denudation. In spite of these factors, the deposits are continuous basinwide (Jaanusson 1982). Beds are undisturbed tectonically except those in the Oslo Region, where they are folded, cleaved and thrust, reaching $500 \mathrm{~m}$ in thickness (Owen et al. 1990). In addition, the sparsely distributed allochthonous deposits follow the $1800 \mathrm{~km}$ long Caledonian front (Bruton et al. 1985). The studied area, northern Estonia and Ingria (the old province of the St. Petersburg region between the Narva and Syas rivers), constituted the shallowest part of the basin. During Hunneberg and early Billingen time, terrigenous sediments were settling in the east (Estonia and Ingria), whereas limestones, mudstones, and shales were deposited to the west (Sweden and the Oslo Region; Fig. 3).

In Estonia the Lower Ordovician succession is represented by quartzose sandstones of the Kallavere Formation, dark laminated graptolite argillites of the Türisalu Formation, and light claystone of the Varangu Formation of the Tremadoc Age, followed by glauconitic silts, sands or calcareous sandstones of the Leetse Formation, and glauconitic limestones of the Toila Formation of the Arenig Age (Männil \& Meidla 1994). The earliest Ordovician trilobites occur in the Mäeküla Member, the most carbonaceous upper part of the Leetse Formation.

\section{LITHOLOGY AND TAPHONOMY}

\section{Mäeküla Member}

The Mäeküla Member consists of alternating variously dolomitized glauconitic sandstone, calcareous sandstone, and glauconitic sandy limestone, with clay laminae or layers often covering discontinuity surfaces. The common thickness of the member in outcrops is about $0.4 \mathrm{~m}$. Disarticulated skeletal parts of trilobites are often preserved on the upper or lower surface of sandstone layers or nodules (at Jägala, Nõmmeveski, and Saka) covered by clay. The clay probably protected fossils from dolomitization and dissolution, which is seen elsewhere in sandy beds containing rare badly preserved moulds of asaphid fragments. Most of the testiferous cranidia of the cheirurid Krattaspis Öpik discovered on the surfaces (Pärnaste 2003) occur upside down and are tilted forwards, lying on the anterior glabellar lobes, or backwards, lying on the posterior glabellar lobes (Fig. 4A); often they are also tilted sideways onto the fixed cheek, probably the most stable attitude for these trilobite sclerites. This, however, is the reverse of the results of the experiment described for Flexicalymene Shirley (cf. Lask 1993, p. 222), in which the elements were not preserved inverted. Cephala of Krattaspis are also flattened 

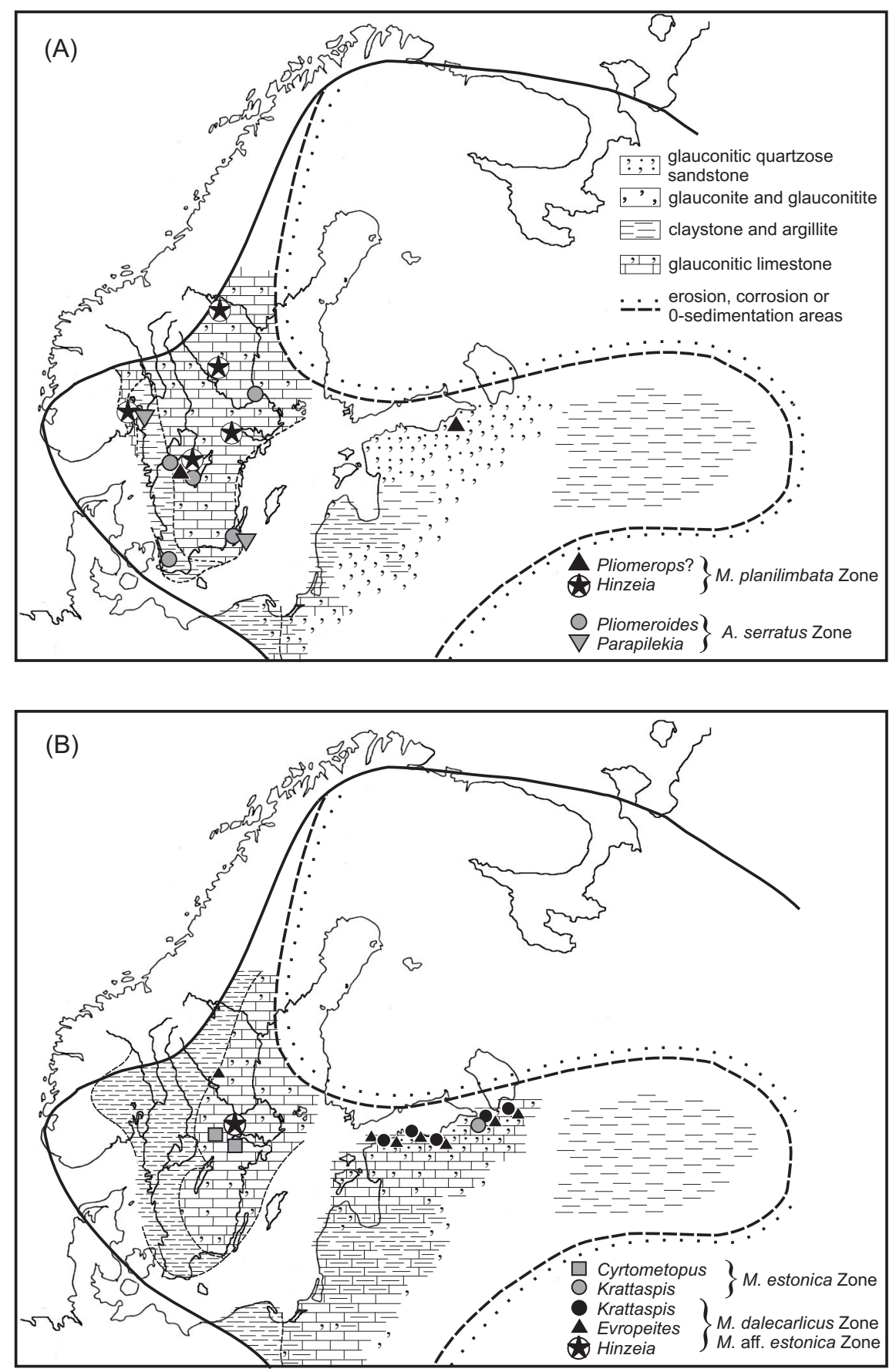

Fig. 3. Facies distribution of the Baltoscandian palaeobasin (modified after Erdtmann 1965; Männil 1966; Laškovas 1968; Modlinski 1976; Erdtmann \& Paalits 1994) showing cheirurin data: (A) during the Hunneberg, for comparison the Tremadoc cheirurins from the A. serratus Biozone are shown (grey filling); (B) during the Billingen (Pärnaste 2004b). 

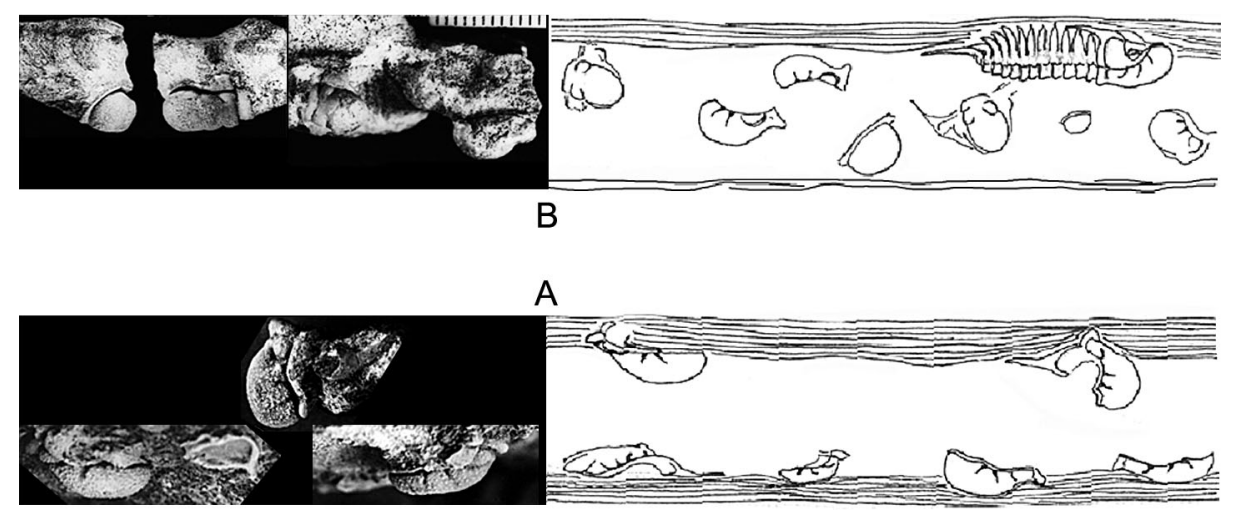

Fig. 4. Orientation of trilobites on the example of Krattaspis: (A) in the Mäeküla Member skeletal parts are mostly oriented upside down and lie on their anteriormost lobes (LA and L3) or on their posteriormost lobes (L2, L1, and L0) on the clayey surface; (B) in the Vassilkovo Beds the skeletal parts are non-oriented and occur throughout the entire layer (Pärnaste 2004b).

and the glabella and furrows are deformed or even distorted (see Pärnaste 2003, text-fig. 6). The deformation was probably a result of compression by relatively large sand bodies deposited during the heavy storms. The clay laminae and layers were formed during quiet periods at a very low rate of sedimentation, when the sediment was reworked by soft-bodied fauna, leaving horizontal and flattened burrows filled with clay. Some thin soft clay layers contain three-dimensional well-preserved trilobites; in claystone they are usually strongly deformed.

\section{Vassilkovo Beds}

The trilobite sclerites are randomly orientated and occur throughout the unit (Fig. 4B), in the argillaceous glauconitic limestones of the Vassilkovo Beds (e.g. Lava section; Figs 1, 5), indicating rapid burial conditions or bioturbation (cf. Speyer 1987). The skeletal remains, varying in size, are better preserved probably due to the lower degree of dissolution within this somewhat finer-grained sediment with a higher clay content.

\section{Päite Member}

The dolomitized limestone unit of the Päite Member is mostly $0.3-0.4 \mathrm{~m}$ thick in Estonia (Orviku 1958, 1960) but exceptionally thick $(1.13 \mathrm{~m})$ at Tõrvajõe (Orviku 1960, p. 56). The average thickness of the unit in the outcrops of Ingria is about $0.7 \mathrm{~m}$ (Dronov et al. 1997a, p. 15; Popov et al. 1997, p. 5; Pushkin \& Popov 1999). Disarticulated sclerites of the isotelines are very abundant throughout the 

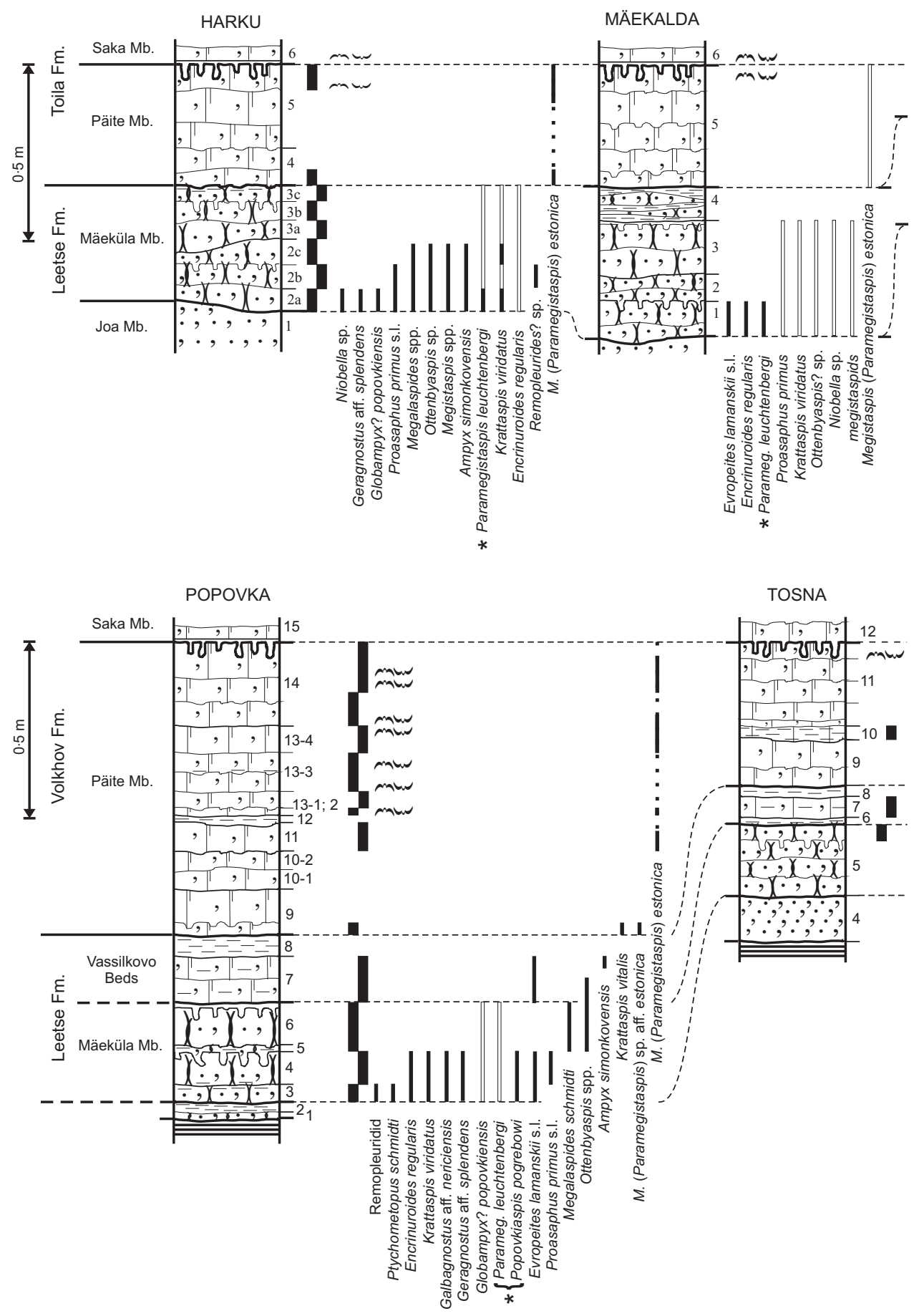

Fig. 5. Trilobite distribution in the sections studied bed by bed. Bed numbers are indicated on the right-hand side of the columns. 

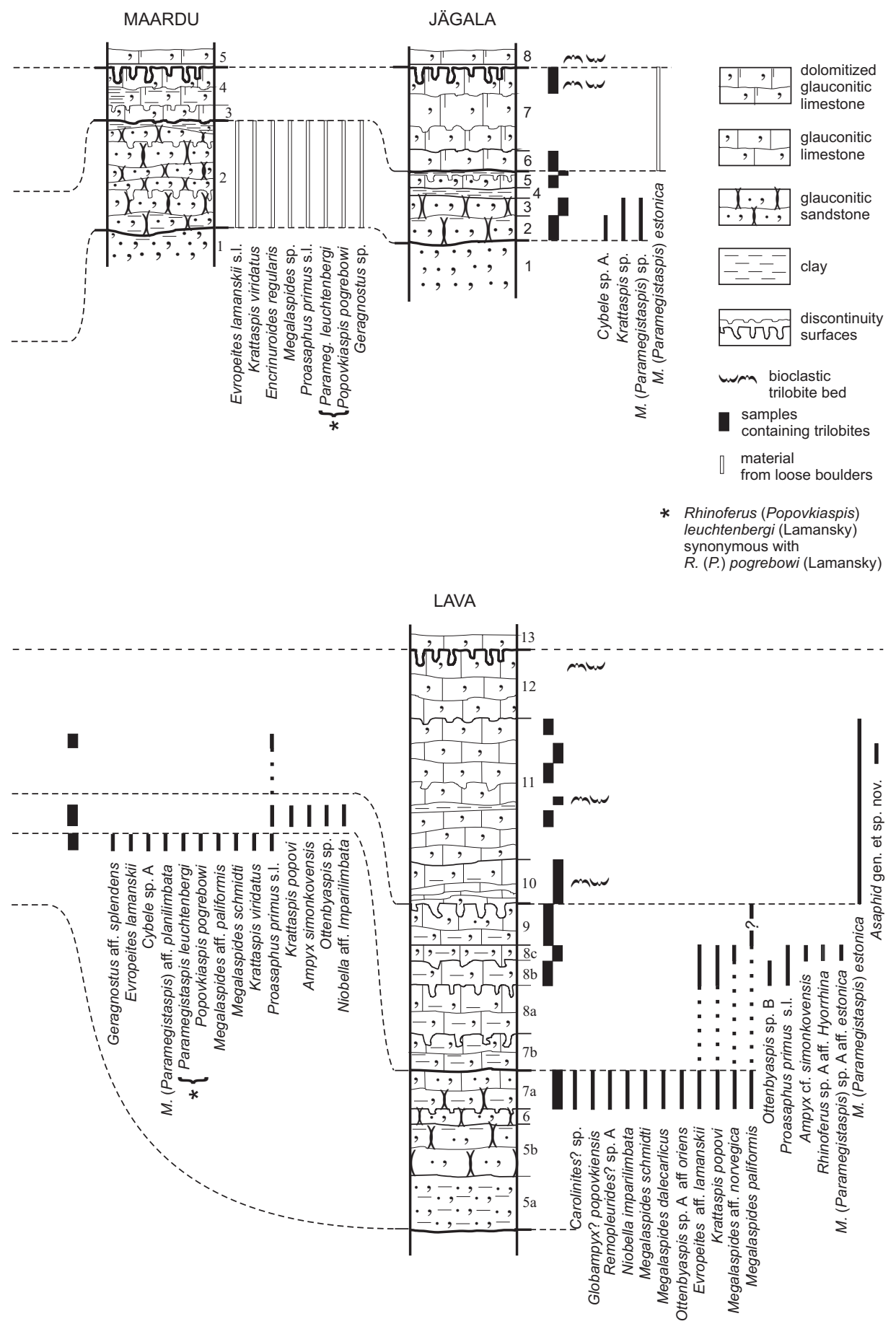

Fig. 5. Continued. 
member, producing so-called trilobite cemeteries, similar to the lowest beds of the overlying Saka Member. Most commonly, the pygidia are preserved arranged horizontally, being generally oriented upside down, showing some degree of sorting processes.

\section{MATERIAL AND METHODS}

This study was initiated by Dr Leonid Popov who kindly gave me his trilobite collection from Ingria. I collected additional material during two expeditions to Ingria in 1986-1987, and numerous spells of fieldwork in Estonia. The new collections contain about 200 cheirurine specimens published earlier (Pärnaste 2002, 2003, 2004b, 2006) as well as over 500 non-cheirurins (Aru 1990; Pärnaste $2001 b$ ), a very large number of megistaspids from the bioclastic beds of the Päite Member excluded. The trilobites were mostly collected by bed-by-bed sampling of strata in all studied localities (Fig. 1).

The thickness of the sampled beds varied from 1 to $10 \mathrm{~cm}$ (rarely to $15 \mathrm{~cm}$; Fig. 5). The slabs of sandstone covered by clay films were brushed clean in river- or seawater to reveal the specimens exposed on top. The slabs were then mechanically broken into small pieces to recover the specimens inside. Samples from thin soft clay layers were washed through a 1-mm sieve to remove the clay, and the residue was examined under the microscope in the laboratory. Some layers were barren but some contained a rich variety of skeletal elements (trilobites, brachiopods, ostracods, bryozoans, echinoderms, and conodonts). In addition, exoskeletons of trilobites exposed by weathering were found on loose boulders at the localities where trilobites of the Mäeküla Member were preserved on the outer surface of the particular beds. As the lithology of the different beds of these thin members is easily recognizable, it was possible to estimate roughly the stratigraphic level of these slabs.

\section{TRILOBITE DISTRIBUTION}

The East Baltic trilobite assemblage of the Mäeküla Member is slightly more diverse near its base than higher and in the Vassilkovo Beds, but is considerably diverse compared to the almost monospecific association of the overlying Päite Member (Fig. 5). However, the latter member is also far less studied. In contrast, the number of specimens increases upwards. A similar trend is described also for the Hagastrand Member limestones of the Hunneberg Stage in the Oslo Region (Hoel 1999).

Compared to the contemporaneous trilobite association in Norway and Sweden several newcomers appear in the East Baltic in addition to the genera spread over the basin. The near-shore environment favoured the appearance of the following 
taxa: the encrinurids Encrinuroides Reed and Cybele Loven, a cheirurid Krattaspis, a pilekiid Evropeites Balashova, and a pharostomatid Ptychometopus Schmidt. Of those, Encrinuroides regularis Pärnaste is the earliest representative of the Encrinurinae: the lineage, which disappeared from Baltoscandia shortly after Billingen time and reappeared not before Oandu time (Pärnaste 2004b, 2006). Also Krattaspis is a stem-group for the Cyrtometopinae Öpik, 1937 (Pärnaste 2003), which evolves in Baltoscandia up to the Keila Age (Pärnaste 2004a). Krattaspis viridatus Öpik occurs usually in the lowest beds of the Mäeküla Member, but $K$. popovi Pärnaste appears in a slightly finer-grained sediment above it (see the Tosna section, Fig. 5). The latter occurs in both the Mäeküla and Vassilkovo beds in the Lava section, where the grain size of the Mäeküla beds is somewhat finer as compared to that in the Popovka or Mäekalda sections; the difference in grain-size hints at the possibility that $K$. popovi might be a facies-related species. However, ontogenetic study reveals evolutionary trends, showing the ancestry of $K$. viridatus. Evolution continues towards $K$. vitalis Pärnaste in the lowest part of the Päite Member and more extensively towards Cyrtometopus priscus Tjernvik, which ranges in the upper part of the Billingen Stage in Sweden. Cyrtometopus Angelin occurs in the Volkhov and Kunda stages, as well as Cybele. The pilekiid Evropeites lamanskii (Schmidt) is quite common in the lowest beds of the Mäeküla Member. A slightly different form of it is found from the same member in the Lava section. Evropeites itself is very rare elsewhere in Baltoscandia. Only one specimen of Evropeites toernquisti (Holm) has been reported from the Billingen Stage in Sweden (Holm 1882) and there are no other records from younger beds or from outside Baltoscandia. Another rare taxon known from the lowest part of the Mäeküla Member is a pharostomatid, Ptychometopus schmidti Balashova, which is closely related to Ptychometopus volborthi Schmidt of the Volkhov Stage. The earliest pharostomatids occur in the Tremadoc of Avalonia, Gondwana, and Southern China (Peng 1990, pp. 72, 117). Two other obscure taxa, the Hunnebergian Celmus? insolita (Tjernvik) from Sweden and the Volkhovian Celmus? longifrons Poulsen from Bornholm, Denmark, deserve further attention as they resemble Ptychometopus. Unfortunately, these taxa are only known from their cranidia, which allows no confident assessment.

One fragmentary cranidium of the globally distributed pelagic Carolinites Ross was collected in the Lava section in addition to the specimen in Popovka (Balashova 1961). Another representative of the pelagic realm, a remopleuridid, occurs in the lowest trilobite beds of the same localities.

A few rare agnostids (Arthrorhachis Hawle \& Corda, Galbagnostus Whittington, and Geragnostus Howell) were also collected from the lowest beds of the Mäeküla Member. These show some affinities with the material described from the shale and limestone beds in the western part of the basin (Tjernvik 1956; Ahlberg 1992). The agnostids and the following groups are under taxonomic revision and are mentioned here as preliminary records. Raphiophorids are relatively 
common; at most localities Globampyx? popovkiensis Balashova appears first, followed by Ampyx simonkovensis Balashova, which much resembles Lonchodomas Angelin. The endemic asaphid Proasaphus Balashova is of similar frequency to raphiophorids, ranging from the Mäeküla to Vassilkovo beds, and has also been collected in Sweden (figured as genera et species indet. by Tjernvik 1956, pl. 10, figs 7, 8). Proasaphus is possibly the ancestor of Asaphus Brongniart (Tjernvik 1956, p. 259) and also of Onchometopus Schmidt, both occurring in the Toila/Volkhov formations just above the Leetse Formation. Proasaphus also resembles Aulacoparia Hintze \& Jaanusson from the Fillmore Formation of Utah (Tjernvik 1956, p. 259), and somewhat Norasaphus Fortey \& Shergold from the Nora Formation in Australia, both from the Lower Ordovician.

Two isoteline taxa, one previously described as Megalaspis leuchtenbergi Lamansky and the other as Megalaspis pogrebovi Lamansky (1905), co-occur in the lowest nodular beds of several localities (Maardu, Nõmmeveski, Popovka, and Tosna; Fig. 5). The former species was later assigned to Paramegistaspis Balashova and the latter to Rhinoferus? (Popovkiaspis) Balashova (1976). Apparently they are conspecific and belong to Rhinoferus Balashova, differing from its younger relatives in having, analogously to all other Hunnebergian-Billingenian isotelines, illdefined furrows on the posterior parts of the glabella. Of the more common species, Megalaspides paliformis Tjernvik and M. dalecarlicus (Holm) are known from the upper part of the Mäeküla and in the Vassilkovo beds, but usually absent from the lowermost part of the former unit; other rare Megalaspides species are found in the lowest beds. Megistaspis (Paramegistaspis) ranges through the studied section, being very sparse at the beginning, but very common in the top. Additionally, some other poorly preserved, obscure isotelines were described by Balashova in 1966 as $M$. (P.) planilimbata rossica, $M$. (P.) putilovensis, $M$. (P.) popovkiensis, and Megalaspides (Lannacus) popovkiensis. The species $M$. (P.) popovkiensis and M. (P.?) scutata Tjernvik show several similarities to Megistaspis (Megistaspis) Jaanusson, being likely ancestors of the latter. Similarly, Megalaspides $(L$.) popovkiensis is the possible ancestor of Rhinoferus (Lawiaspis) Balashova, and is rather different from Megalaspides itself. Also Megalaspides (M.) dalecarlicus balticus Balashova apparently belongs to Protoptychopyge Balashova, bringing down the first appearance of that group. In addition, I have recorded a few rare raphiophorids, niobinids, cheirurids, and cybelines from the Päite Member.

\section{TRILOBITE BIOZONATION}

Correlating the Lower Ordovician rocks of northwestern Russia and Estonia with those of Scandinavia, Lamansky (1905) recognized the Scandinavian Megalaspis limbata and Megalaspis planilimbata zones in the lowest limestone unit $\left(\mathrm{B}_{\mathrm{II}} \alpha\right)$ and established the Megalaspides Zone in the underlying calcareous Glauconite 
Sandstone (BI $\beta$; Fig. 2). Balashova (1966) recognized five local trilobite zones within the interval now interpreted as the Billingen Stage. Her lowest zone was correlated with the upper Tremadoc and the following zones with the lower Arenig. Unfortunately, her correlation (dotted lines with an arrow in Fig. 2) of the Mäeküla sandstones with the Apatokephalus serratus Biozone was based on several erroneous identifications. The first of these is the fragment she named A. serratus (Boeck), which actually belongs to Remopleurides Portlock (Pärnaste 2004a, b). Second, a very tiny and poorly preserved fragmentary cranidium referred to Euloma ornatum Angelin (Balashova 1966, pl. 1, fig. 1) most probably belongs to Ptychometopus schmidti. Third, the new subspecies of Pliomeroides primigenus (Angelin) was recorded as indicating the A. serratus Biozone. However, the taxon Pliomeroides (Evropeites) primigenus lamanskii (Schmidt) is rather different and has been variously considered as an independent genus (Fortey 1980, p. 86), as well as a taxon of species rank - namely Evropeites lamanskii (Tjernvik 1956, p. 184; Aru 1990, p. 72; Ebbestad 1999, p. 107). Lamansky (1905, p. 6, pl. 1, fig. 1) mistakenly identified a fragment of the latter species as the Tremadocian Triarthrus angelini Linnarsson. Also, a fragmentary pygidium attributed to the index species of the succeeding Megistaspis (Ekeraspis) armata Biozone (Balashova 1966, p. 16, pl. 2, fig. 12) is too poorly preserved to allow a confident identification, and judging by the original, it appears that the retouching and cutting of the figure is rather subjective. This leaves no evidence therefore, which confirms that any of these (A. serratus and $M$. (E.) armata) Scandinavian trilobite zones can be recognized in the East Baltic.

Determination of the succeeding Swedish zones in the East Baltic is somewhat complicated. In particular, during the holaspid period, the isotelines (the index trilobites) vary considerably in their diagnostic characters (e.g. the number of pleural segments and length/width ratios of the axis or cephala and pygidia in general; Nielsen 1995). The width of the pygidium and number of its pleurae increase on Megistaspis (Paramegistaspis) during the holaspid period. The same tendency is observed in the phylogenetic lineage $M$. (P.) planilimbata-aff. estonica-estonica. The relatively narrow pygidium of $M$. $(P$. $)$ planilimbata has six pleural ribs, and that of the stratigraphically younger $M$. (P.) estonica eight ribs, being also slightly wider. Unfortunately, the hitherto published material of M. (Paramegistaspis) does not allow adequate comparison of species and a study of growth variation is needed. However, some dubiously identified pygidia of $M$. (P.) planilimbata from the Tosna River locality indicate probable occurrence of the eponymous zone in the eastern Baltic. Pliomerops? linnarssoni known from the Megistaspis planilimbata Biozone in Skultrop, Västergötland (Wiman 1906; Tjernvik 1956, p. 128), has also been identified from Lamoshka (Fig. 3), which further supports that sign. Trilobites indicative of the Megistaspis (P.) aff. estonica Biozone in Sweden, such as Pricyclopyge gallica (Tjernvik) and Raymondaspis brevicauda Tjernvik, have not been recorded eastwards. However, there is a potential to use for correlation 
some undescribed taxa mentioned by Tjernvik (1956), belonging to the genera such as Geragnostus, Symphysurus Goldfuss, and Megalaspides Brøgger.

At most of the studied localities the trilobite assemblage of the lowest part of the Mäeküla Member contains Evropeites lamanskii. Until further study proves the applicability of Scandinavian isoteline zonation in the East Baltic, the earlier established Evropeites lamanskii Biozone (see Popov et al. 1997, fig. 2, after Balashova 1966) is temporarily accepted for that assemblage, which is correlated with the Megistaspis (P.) aff. estonica Biozone in Sweden. However, this species is closely related to Evropeites toernquisti (Pärnaste 2002, 2004b), known only from the type specimen from the Megalaspides dalecarlicus Biozone in Dalarna (Tjernvik \& Johansson 1980, p. 187). If the appearance of this particular genus in the Baltoscandian palaeobasin was synchronous basinwards, this association containing E. lamanskii could be correlated with the Megalaspides $(M$.$) dalecarlicus$ Biozone. However, as Evropeites is possibly a descendant of the Tremadoc Anacheirurus Reed from Avalonia, or Pliomeroides Harrington \& Leanza from Argentina and Baltica, then during the early Arenig it could first evolve in the near-shore area (Estonia, Ingria) and afterwards migrate further offshore (Sweden), being represented in both the Megistaspis planilimbata and Megalaspides dalecarlicus biozones.

Agnostids, pliomerids, and encrinurids are lacking in the trilobite association of the clay-rich Vassilkovo Beds, where both Megalaspides (M.) dalecarlicus and Megalaspides paliformis are common. The latter is an index species for the upper part of the Megalaspides (M.) dalecarlicus Biozone in Sweden. In addition, Krattaspis, Proasaphus, and Ottenbyaspis Bruton are rather common, but Rhinoferus? (Popovkiaspis) is rare.

A new, almost monospecific association comprising Megistaspis (Paramegistaspis) estonica appears in the Päite Member, and characterizes the eponymous zone, which can be correlated across Baltoscandia. The appearance of Megistaspis (Megistaspis) Jaanusson just above the discontinuity surface of the "Püstakkiht" marks the Billingen-Volkhov boundary. Both the index trilobite Megistaspis (Megistaspis) polyphemus (Brøgger) $[=$ M. lata (Törnquist) synonymized by Nielsen 1995] and M. (M.) limbata baltica Balashova are very abundant in the overlying Saka Member of the Volkhov Stage.

\section{CONCLUSIONS}

The study of the Lower Ordovician trilobites in the Mäeküla and Päite members of Estonia and northwestern Russia shows that most previous correlations with Scandinavian trilobite zones are in error because of misidentification of stratigraphically significant species. In contrast to the conclusions of Balashova (1966), there is no sound evidence of the occurrence of the trilobites of the Apatokephalus 
serratus and Megistaspis (Ekeraspis) armata biozones in the East Baltic, whilst there is evidence of the occurrence of the Megistaspis (Paramegistaspis) planilimbata and M. (P.) aff. estonica biozones at some localities. The Megalaspides dalecarlicus Biozone is represented in Estonia and Ingria, especially by its upper part indicated by the appearance of Megalaspides paliformis, observed in the Vassilkovo Beds in Ingria just below the M. (P.) estonica Biozone. The latter is the lithologically homogeneous interval traced on the glauconitic limestone succession throughout Baltoscandia, containing skeletons of the index trilobite settled as the "trilobite cemeteries". Consequently, this study shows that the faunal association of different beds of the Mäeküla Member varies by locality, indicating diachrony of the lowest calcareous beds of Estonia and Ingria (Pärnaste 2003).

\section{ACKNOWLEDGEMENTS}

I am grateful to Dr Leonid Popov (Cardiff), who kindly gave me the collection of trilobites from the St. Petersburg Region, and to Dr Ivar Puura, who read the first draft of the manuscript and improved its language. My sincere thanks are addressed to the referees Dr Philip D. Lane from Keele University and Prof. Dimitri Kaljo from the Institute of Geology at Tallinn University of Technology for their helpful reviews and detailed corrections. Vivianne Berg-Madsen, a curator of the Museum of Evolution, Uppsala University, is thanked for loan of Tjernvik's originals. Financial support of the Estonian Science Foundation (grants Nos 5922 and 6127) is acknowledged. This investigation is a contribution to the International Geological Correlation Program Project No. 503 "Ordovician Palaeogeography and Palaeoclimate".

\section{REFERENCES}

Ahlberg, P. 1992. Agnostid trilobites from the Lower Ordovician of southern Sweden. Trans. Roy. Soc. Edinburgh, Earth Sci., 83, 539-570.

Aru, H. 1990. Ordovician trilobites. In Field Meeting Estonia 1990. An Excursion Guidebook (Kaljo, D. \& Nestor, H., eds), pp. 72-73. Estonian Academy of Sciences, Tallinn.

Balashova, Ye. A. 1961. Discovery of a new trilobite in the glauconite series of the Baltic region. Paleontol. J., 3, 129-132 (in Russian).

Balashova, Ye. A. 1966. Trilobites of the lower Ordovician rocks of the Russian Platform. Vopr. Paleontol., 5, 3-22 (in Russian).

Balashova, Ye. A. 1976. Systematics of asaphine trilobites and their representatives in the USSR. Nedra, Leningrad (in Russian).

Bergström, S. M. 1988. On Pander's Ordovician conodonts: distribution and significance of the Prioniodus elegans fauna in Baltoscandia. Senckenbergiana Lethaea, 69, 3/4, 217-251.

Bruton, D. L., Lindström, M. \& Owen, A. W. 1985. The Ordovician of Scandinavia. In The Caledonide Orogen - Scandinavia and Related Areas (Gee, D. G. \& Stuart, B. A., eds), pp. 237-282. Wiley, Chichester. 
Cooper, R. A. \& Lindholm, K. 1990. A precise worldwide correlation of early Ordovician graptolite sequences. Geol. Mag., 127, 497-525.

Dronov, A. V., Koren, T. N., Popov, L. E., Tolmacheva, T. Ju. \& Holmer, L. E. 1995. Uppermost Cambrian and Lower Ordovician in northwestern Russia: sequence stratigraphy, sea level changes and bio-events. In Ordovician Odyssey: Short Papers From the Seventh International Symposium on the Ordovician System (Cooper, J. D., Droser, M. L. \& Finney, S. C., eds), pp. 319-322. SE (Society for Sedimentary Geology), Fullerton, California.

Dronov, A. V., Fedorov, P. V., Popov, L. E., Ivantsov, A. Ju. \& Tolmacheva, T. Ju. 1997a. Middle Cambrian to Middle Ordovician in Lava river canyon and Putilovo quarry. In WOGOGOB Excursion Guide, St. Petersburg, Russia, 1997 (Popov, L. E., ed.), pp. 13-19. Uppsala University.

Dronov, A. V., Popov, L. E. \& Tolmacheva, T. Ju. 1997b. Tosna river valley. In WOGOGOB Excursion Guide, St. Petersburg, Russia, 1997 (Popov, L. E., ed.), pp. 19-23. Uppsala University.

Ebbestad, J. O. R. 1999. Trilobites of the Tremadoc Bjørkåsholmen Formation in the Oslo Region, Norway. Fossils Strata, 47.

Erdtmann, B.-D. 1965. Outline stratigraphy of graptolite-bearing 3b (Lower Ordovician) strata in the Oslo Region, Norway. Norsk Geol. Tidsskr., 45, 481-547.

Erdtmann, B.-D. \& Paalits, I. 1994. The Early Ordovician "Ceratopyge Regressive Event" (CRE): its correlation and biotic dynamics across the East European Platform. Geologija (Vilnius), 1994, 17, 36-57.

Fortey, R. A. 1980. The Ordovician trilobites of Spitsbergen. III. Remaining trilobites of the Valhallfonna Formation. Norsk Polarinst. Skr., 171.

Hoel, O. A. 1999. Trilobites of the Hagastrand Member (Tøyen Formation, lowermost Arenig) from the Oslo Region, Norway. Part II: Remaining non-asaphid groups. Norsk Geol. Tidsskr., 79, 259-280.

Holm, G. 1882. Ueber einige Trilobiten aus dem Phyllograptusschiefer Dalekarliens. Bihang Svenska Vetensk.-Akad. Handl., 6(9), 1-16.

Jaanusson, V. 1951. Yttrande med anledning av T. Tjernviks föredrag om lägsta ordoviciska largen i Närke. $G F F, \mathbf{7 3}, 530-532$

Jaanusson, V. 1960. Graptoloids from the Ontikan and Viruan (Ordovician) limestones of Estonia and Sweden. Bull. Geol. Univ. Uppsala, 38, 289-366.

Jaanusson, V. 1976. Faunal dynamics in the Middle Ordovician (Viruan) of Baltoscandia. In The Ordovician System (Bassett, M. G. ed.), pp. 301-326. University of Wales Press, Cardiff.

Jaanusson, V. 1982. Introduction to the Ordovician of Sweden. In Field Excursion Guide, IV International Symposium on the Ordovician System (Bruton, D. L. \& Williams, S. H., eds). Paleont. Contrib. Univ. Oslo, 279, 1-9.

Lamansky, W. W. 1905. Die aeltesten silurischen Schichten Russlands (Etage B). Mém. Comité Géol., Nouv. Sér. Livraison, 20.

Lask, P. B. 1993. The hydrodynamic behavior of sclerites from the trilobite Flexicalymene meeki. Palaios, 8, 219-225.

Laškovas, E. 1968. Lithostratigraphic complexes of the Lower Ordovician of the southern Baltic. In Stratigraphy of the Baltic Lower Palaeozoic and Its Correlation with Other Areas (Grigelis, A., Kaljo, D., Männil, R., Paškevičius, J., Sokolov, B., Tomczyk, H. \& Ulst, R., eds), pp. 139-154. Mintis, Vilnius (in Russian).

Lindholm, K. 1991a. Hunnebergian graptolites and biostratigraphy in southern Scandinavia. Lund Publ. Geol., 95, 1-36.

Lindholm, K. 1991b. Ordovician graptolites from the early Hunneberg of southern Scandinavia. Palaeontology, 34, 283-327.

Lindström, M. 1957. Two Ordovician conodont faunas found with zonal graptolites. GFF, 79, 161-178.

Lindström, M. 1971. Lower Ordovician conodonts of Europe. Mem. Geol. Soc. Amer., 127, 21-61.

Löfgren, A. 1993. Conodonts of the lower Ordovician at Hunneberg, south-central Sweden. Geol. Mag., 130, 215-232. 
Löfgren, A. 1994. Arenig (Lower Ordovician) conodonts and biozonation in the eastern Siljan District, central Sweden. J. Paleont., 68, 1350-1368.

Löfgren, A. 1996. Lower Ordovician conodonts, reworking, and biostratigraphy of the Orreholmen quarry, Västergötland, south-central Sweden. GFF, 118, 169-183.

Löfgren, A. 1997. Conodont faunas from the upper Tremadoc at Brattefors, south-central Sweden, and reconstruction of the Paltodus apparatus. GFF, 119, 257-266.

Mägi, S. 1984. A characterization of the type section of the Ontikan Subseries. Proc. Acad. Sci. Estonian SSR Geol., 33, 104-112 (in Russian).

Mägi, S. 1990. Ontika clint. In Field Meeting Estonia 1990. An Excursion Guidebook (Kaljo, D. \& Nestor, H., eds), pp. 148-153. Estonian Academy of Sciences, Tallinn.

Mägi, S. \& Viira, V. 1976. On distribution of conodonts and inarticulate brachiopods in Ceratopyge and Latorpian Stages. Proc. Acad. Sci. Estonian SSR Chem. Geol., 25, 312-318 (in Russian).

Mägi, S., Viira, V. \& Aru, H. 1989. On the correlation of the Tremadocian and Arenigian boundary beds in the East Baltic. Proc. Acad. Sci. Estonian SSR Geol., 38, 63-67.

Maletz, J., Löfgren, A. \& Bergström, S. M. 1996. The base of the Tetragraptus approximatus Zone at Mt. Hunneberg, S.W. Sweden: a proposed global stratotype for the base of the second series of the Ordovician System. Newsl. Stratigr., 34, 129-159.

Männil, R. 1966. Evolution of the Baltic Basin During the Ordovician. Valgus, Tallinn (in Russian).

Männil, R. \& Meidla, T. 1994. The Ordovician System of the East European Platform (Estonia, Latvia, Lithuania, Byelorussia, parts of Russia, the Ukraine and Moldova). In The Ordovician System of the East European Platform and Tuva (Southeastern Russia) (Webby, B. D., Ross, R. J. \& Yong, Y. Zhen, eds). IUGS Publ., 28, A, 1-52.

Modliński, Z. 1976. Stratigraphy and lithofacies of the Ordovician in the western part of the PeriBaltic Syneclise. Biul. Inst. Geologicznego, 270, 85-108.

Nielsen, A. T. 1995. Trilobite systematics, biostratigraphy and palaeoecology of the Lower Ordovician Komstad Limestone and Huk Formations, southern Scandinavia. Fossils Strata, 38.

Öpik, A. A. 1937. Trilobiten aus Estland. Acta Comment. Univ. Tartuensis, A, 32, 3, 1-163, pls 1-26.

Orviku, K. 1958. Lithostratigraphy of the Toila and Kunda stages of Estonia. In Tezisy dokladov nauchnoj sessii, posvyashchennoj 50-j godovshchine so dnya smerti akademika F. B. Schmidta (Orviku, K., ed.), pp. 30-34. Institut Geologii, Akademiya nauk Éstonskoj SSR, Tallinn (in Russian).

Orviku, K. 1960. Über die lithostratigraphie der Wolkhow- und der Kunda-Stufe in Estland. ENSV TA Geol. Inst. Uurimused, 5, 45-87 (in Russian).

Owen, A. W., Bruton, D. L., Bockelie, J. F. \& Bockelie, T. G. 1990. The Ordovician succession of the Oslo Region, Norway. Norges Geol. Unders. Spec. Publ., 4.

Pärnaste, H. 2001a. On the systematic position of cyrtometopinine (Cheiruridae) trilobites. In Third International Conference on Trilobites and Their Relatives, Oxford, April 2001, Abstracts, pp. $24-25$.

Pärnaste, H. 2001b. The Billingenian trilobites of the northern East Baltic. In Working Group on the Ordovician Geology of Baltoscandia, Öresund Region, mid-May 2001, Abstracts (Harper, D. A. T. \& Stouge, S., eds), pp. 20-21. Copenhagen.

Pärnaste, H. 2002. The Lower Ordovician Pilekiidae and Pliomeridae (Trilobita) of Baltoscandia. In The Fifth Baltic Stratigraphical Conference. "Basin Stratigraphy-Modern Methods and Problems", Extended Abstracts (Satkunas, J. \& Lazauskiene, J., eds), pp. 151-153. Geological Survey of Lithuania, Vilnius.

Pärnaste, H. 2003. The Lower Ordovician trilobite Krattaspis: the earliest cyrtometopinid (Cheiruridae) from the Arenig of the East Baltic. Spec. Pap. Palaeontol., 70, 241-257.

Pärnaste, H. 2004a. The trilobite zonation of the Billingen Stage in the East Baltic. In Working Group on the Ordovician Geology of Baltoscandia, Estonia, May 2004, Abstracts (Hints, O. \& Ainsaar, L., eds), pp. 81-82. Tartu University Press, Tartu.

Pärnaste, H. 2004b. Early Ordovician Trilobites of Suborder Cheirurina in Estonia and NW Russia: Systematics, Evolution and Distribution. Tartu University Press, Tartu. 
Pärnaste, H. 2006. The earliest encrinurid trilobites from the East Baltic and their taxonomic interest. Palaeontology, 49, 155-170.

Peng, Shanchi 1990. Tremadoc stratigraphy and trilobite faunas of northwestern Hunan. Beringeria, 2.

Popov, L. E., Dronov, A. V. \& Ivantsov, A. Ju. 1997. Outline of geology and stratigraphy. In WOGOGOB Excursion Guide, St. Petersburg, Russia, 1997 (Popov, L. E., ed.), pp. 2-9. Uppsala University.

Pushkin, V. I. \& Popov, L. E. 1999. Early Ordovician bryozoans from north-western Russia. Palaeontology, 42, 171-189.

Schmidt, F. 1904. Revision der ostbaltischen Trilobiten. Abtheilung V: Allgemeine Übersicht mit Nachträgen und Verbesserungen. Mém. Acad. Impér. Sci. St-Pétersbourg (8), 14(10), 1-68, pls $1-8$.

Schmidt, F. 1907. Revision der ostbaltischen Trilobiten. Abtheilung VI: Allgemeine Übersicht mit Nachträgen und Verbesserungen. Mém. Acad. Impér. Sci. St-Pétersbourg (8), 20(8), 1-104, pls $1-3$.

Scotese, C. R. \& McKerrow, W. S. 1990. Revised World maps and introduction. In Palaeozoic Palaeogeography and Biogeography (McKerrow, W. S. \& Scotese, C. R., eds). Geol. Soc. London Mem., 12, 1-12.

Speyer, S. E. 1987. Comparative taphonomy and palaeoecology of trilobite lagerstatten. Alcheringa, 11, 205-232.

Tjernvik, T. E. 1956. On the early Ordovician of Sweden, stratigraphy and fauna. Bull. Geol. Univ. Uppsala, 36, 107-284.

Tjernvik, T. E. \& Johansson, J. V. 1980. Description of the upper portion of the drill-core from Finngrundet in the South Bothnian Bay. Bull. Geol. Univ. Uppsala NS, 8, 173-204.

Torsvik, T. H. 1998. Palaeozoic palaeogeography: a North Atlantic viewpoint. GFF, 120, 109-118.

Viira, V., Löfgren, A., Mägi, S. \& Wikström, J. 2001. An Early to Middle Ordovician succession of conodont faunas at Mäekalda, northern Estonia. Geol. Mag., 138, 699-718.

Wiman, C. 1906. Pliomera Linnarssoni n. sp. Paläontologische Notizen 7-12. Bull. Geol. Inst. Uppsala, 7 (1904-1905), 292-293.

\section{Ida-Balti Vara-Ordoviitsiumi trilobiitide levik ja tsonaalsus}

\section{Helje Pärnaste}

On vaadeldud Kirde-Venemaa ja Põhja-Eesti Vara-Ordoviitsiumi trilobiitide levikut ning tsonaalsust ja võrreldud seda Rootsi läbilõikega, mida 1956. aastal kirjeldas põhjalikult Tjernvik. Ida-Balti läbilõigete biostratigraafilisel liigestamisel on trilobiitide tsonaalne levik olnud üheks oluliseks argumendiks alates juba 1905. aastast, mil Lamansky kirjeldas kuus biostratigraafilist üksust. Neist kaks alumist vastavad artiklis käsitletud Mäeküla ja Päite kihistikele (Hunnebergi/Billingeni lademed), ulatudes lasuvasse Saka kihistikku (Volhovi lade).

On selgitatud, et paljud varasemad korrelatsioonid Skandinaavia trilobiiditsoonidega on olnud ekslikud ja seda peamiselt stratigraafiliselt tähtsate liikide (Apatokephalus serratus, Ceratopyge forficula, Euloma ornatum, Pliomeroides primigenus, Triarthrus angelini) vale identifitseerimise tõttu. Sellest tulenevalt on Mäeküla kihistikku peetud Tremadoki-ealiseks, kuid revisjoni alusel on tegemist nooremate ehk Arenigi-ealiste kihtidega. Erinevalt Rootsi aladest puudu- 
vad Põhja-Eestis ja Loode-Venemaal trilobiidid biotsoonidest nagu A. serratus (Varangu lade) ja Megistaspis (Ekeraspis) armata (Hunnebergi lade), kuid kohati on esindatud (esialgse määratluse järgi) Megistaspis (Paramegistaspis) planilimbata ja $M$. (P.) aff. estonica biotsoonid. Neist viimane tsoon oli Tjernviku esialgse määratluse järgi loetud Hunnebergi-ealiseks, kuid hiljem Billingeni-ealiseks (seda viimast on järgitud kõigis siinse autori töödes). Järgmine biotsoon ehk Megalaspides dalecarlicus on esindatud nii Eestis kui ka Loode-Venemaal ja selle tsooni ülemine osa, mida tähistab indeksliigi esinemine koos Megalaspides paliformis'ega, on jälgitav Vassilkovo kihtides. Megistaspis $(P$.) estonica biotsoon esineb Päite kihistikus, kus esineb hästi sorteeritud skeletitasemeid, nn trilobiidisurnuaedu, mis on moodustunud enamasti indeksliigist. Kokkuvõtteks näitab trilobiitide levik, et Mäeküla kihistiku formeerumise ehk karbonaatse sedimentatsiooni algus on erinevate paljandite lõikes erinev. 